\title{
Direct cost of monitoring conventional hemodialysis conducted by nursing professionals
}

\section{Custo direto da monitorização da hemodiálise convencional realizada por profissionais de enfermagem}

Costo directo del monitoreo de hemodiálisis convencional realizado por profesionales de enfermería

\section{Antônio Fernandes Costa Lima'}

'Universidade de São Paulo, School of Nursing, Department of Professional Orientation. São Paulo, Brazil.

How to cite this article:

Lima AFC. Direct cost of monitoring conventional hemodialysis conducted by nursing professionals.

Rev Bras Enferm [Internet]. 2017;70(2):357-63. DOI: http://dx.doi.org/10.1590/0034-7167-2016-0447

\author{
Submission: 07-27-2016 Approval: 09-25-2016
}

\section{ABSTRACT}

Objective: to analyze the mean direct cost of conventional hemodialysis monitored by nursing professionals in three public teaching and research hospitals in the state of São Paulo, Brazil. Method: this was a quantitative, explorative and descriptive investigation, based on a multiple case study approach. The mean direct cost was calculated by multiplying (clocked) time spent per procedure by the unit cost of direct labor. Values were calculated in Brazilian real (BRL). Results: Hospital C presented the highest mean direct cost (BRL 184.52), 5.23 times greater than the value for Hospital A (BRL 35.29) and 3.91 times greater than Hospital B (BRL 47.22). Conclusion: the costing method used in this study can be reproduced at other dialysis centers to inform strategies aimed at efficient allocation of necessary human resources to successfully monitor conventional hemodialysis.

Descriptors: Hospital Hemodialysis Units; Nephrology Nursing; Costs and Cost Analysis; Direct Service Costs; Benchmarking.

\section{RESUMO}

Objetivo: analisar o custo direto médio relativo à participação de profissionais de enfermagem no procedimento de monitorização da hemodiálise convencional, em três hospitais públicos de ensino e pesquisa do estado de São Paulo. Método: pesquisa quantitativa, exploratório-descritiva, na modalidade de estudos de casos múltiplos. O custo direto médio foi calculado multiplicando-se o tempo (cronometrado) despendido, na execução do procedimento, pelo custo unitário da mão de obra direta. Para a realização dos cálculos, utilizou-se a moeda brasileira (R\$). Resultados: obteve-se o maior custo direto médio no Hospital C (R\$ 184,52), valor 5,23 vezes maior do que o valor do Hospital A ( $R \$ 35,29)$ e 3,91 maior do que o valor do Hospital $B(R \$ 47,22)$. Conclusão: a metodologia de custeio desenvolvida poderá ser reproduzida em outros Centros de Diálise, a fim de subsidiar a proposição de estratégias visando à eficiência alocativa dos recursos humanos requeridos para o êxito da monitorização da hemodiálise convencional.

Descritores: Unidades Hospitalares de Hemodiálise; Enfermagem em Nefrologia; Custos e Análise de Custo; Custos Diretos de Serviços; Benchmarking.

\section{RESUMEN}

Objetivo: analizar el costo directo promedio derivado de la participación de profesionales de enfermería en el monitoreo de hemodiálisis convencional, en tres hospitales públicos de enseñanza e investigación del estado de São Paulo. Método: investigación cuantitativa, exploratorio-descriptiva, modalidad de casos múltiples. El costo directo promedio fue calculado multiplicando el tiempo (cronometrado) utilizado en la ejecución del procedimiento por el costo unitario de la mano de obra directa. Para realizar el cálculo se utilizó la moneda brasileña (Real, R\$). Resultados: el mayor costo directo promedio se obtuvo en el Hospital C ( $R \$ 184,52)$, valor 5,23 mayor que el del Hospital A $(R \$ 35,29)$ y 3,91 veces mayor que el del Hospital $B(R \$$ $47,22)$. Conclusión: la metodología de costeo desarrollada podrá replicarse en otros Centro de Diálisis, con el fin de ayudar con la propuesta de estrategias para el éxito del monitoreo de la hemodiálisis convencional.

Descriptores: Unidades de Hemodiálisis en Hospital; Enfermería en Nefrología; Costos y Análisis de Costo; Costos Directos de Servicios; Benchmarking.

\section{CORRESPNDING AUTHOR Antônio Fernandes Costa LimaＥ-mail: tonifer@usp.br}




\section{INTRODUCTION}

In recent decades, the global prevalence of chronic kidney disease (CKD) has increased, requiring more and more attention from health systems and professionals, due to its association with significant morbidity, mortality and high-costing treatments (1-3). These have a considerable impact on the institutional public health budget and health care programs in several countries ${ }^{(4-6)}$.

CKD is a silent disease and patients are frequently diagnosed only at advanced stages, when renal replacement therapy is required to ensure survival ${ }^{(7)}$. For almost four decades, traditionally, most CKD patients have adopted some form of dialysis ${ }^{(8)}$, with hemodialysis (HD) as the main type ${ }^{(5-6,9)}$.

In Brazil, CKD patient care is one of the main areas that compose the high complexity of the Unified Health System (SUS), consuming a great volume of financial resources from the outpatient budget ${ }^{(10)}$. As is the case in several countries, conventional hemodialysis (CHD) is the most commonly used form of renal replacement therapy, which requires investing in new technology and the ongoing qualification of health professionals.

According to current Brazilian legislation, health team members must remain in the dialysis environment during the entire HD session and provide care during hemodialysis. ${ }^{(11-13)}$ Although this function is not an exclusive prerogative of nursing professionals, nurses and nursing technicians ${ }^{(13)}$ are present at all times: before, during and after dialysis.

In the extracorporeal circuit formed during dialysis, CKD or acute kidney injury (AKI) patients are hooked to an arterial line (tubing), dialyzer, and venous line (tubing), which are connected to a machine with panels containing electronic devices that continually monitor extracorporeal blood circulation and the circulation of the dyalisate inside the dialyzer. During this period, nurses, nursing technicians, and nursing aides must observe not only the patient, monitoring the occurrence of possible complications, but also the proper functioning of the HD machine, whose audible and visual alarms require immediate action in order to minimize/resolve the problem identified.

Furthermore, nursing professionals are also responsible for maintaining a calm, harmonious and comfortable environment; providing emotional support; offering/stimulating recreational activities; enabling/encouraging emotional expression; and observing patients' verbal and nonverbal communication ${ }^{(14)}$. Thus, CHD monitoring is a direct intervention essential to ensuring patient safety and the quality of care provided at dialysis centers; however, the costs of this service are not well known.

Growing CHD costs have demanded attention from hospital managers, health professionals and healthcare payers, especially in the hospital context. Such growth in costs, associated with scarce financial resources, has made cost control increasingly relevant. Both public and private hospitals have been pressured to restructure their management policies to ensure survival. In this context, cost control represents an essential strategy ${ }^{(15)}$.

Therefore, costing healthcare services, such as CHD monitoring, in order to improve their management while maintaining quality of care is a necessary and indispensable step to inform the rational allocation of the necessary staff. From this perspective, the aim of this study was to analyze the mean direct cost (MDC) of nursing professionals monitoring conventional hemodialysis (CHD), in three public teaching and research hospitals in the state of São Paulo, Brazil.

\section{METHOD}

\section{Ethical aspects}

First, this study obtained the approval of the boards of nursing and teaching and research coordinating bodies/committees of each hospital. Next, it was submitted to and approved by the USP School of Nursing and the hospitals' research and ethics committee.

\section{Design, setting, and period of the study}

This was a quantitative, exploratory and descriptive investigation, which adopted a multiple case study approach ${ }^{(16)}$. It was conducted at the dialysis centers (DCs) of three public teaching and research hospitals. Observations took place from May 5 to June 7, 2014, Monday to Saturday, in the morning and afternoon shifts.

The first hospital was an autarchy under special regimen associated with a public university maintained by the São Paulo state government, and linked to the State Secretariat for Economic, Scientific and Technological Development, via one of its teaching units. The second hospital belonged to a public federal university, and the third was a complementary entity to a public university maintained by the state of São Paulo and linked to the State Secretariat for Economic, Scientific and Technological Development.

The DCs were selected for this study based on their reputation for good nursing practices and adequate technological structure and human resources (both in terms of quantity and quality) in caring for the demands of CKD patients, in accordance with current Brazilian legal provisions ${ }^{(11-13)}$.

\section{Population or sample; inclusion and exclusion criteria}

Minimum sample size was set at 100 observations, a calculation based on a $95 \%$ confidence level and a 10\% margin of error. Therefore, the sample comprised 657 observations of "CHD session monitoring". To find the direct cost of this procedure, the field observers recorded the length of $\mathrm{CHD}$ sessions and the number of patients and nursing professionals, per shift, at the three DCs.

Study protocol (described in a way that allows for replication) The MDC of the chosen procedure $\left(\overline{C\left(P_{\imath}\right)}\right)$ consisted of the MDC of labor $\left(\overline{C\left(P_{\imath}\right)_{\text {mob }}}\right)$, obtained by the sum of the mean cost $\left(\overline{C h_{c}}\right)$ for each professional category involved, as represented by equation 1: $\overline{C\left(P_{\imath}\right)_{m o b}}=\sum_{c=1}^{n} \overline{C h_{c}}$.

The mean cost of each professional category $\left(\overline{C h_{c}}\right)$ was the product of the mean time spent by category $(\mathbf{c})$ per procedure ( $\left.\overline{\boldsymbol{t}_{c}}\right)$ and the mean unit cost of labor $\left(\overline{S u_{c}}\right)$ for each professional category $(\mathbf{c}): \overline{C h_{c}}=\overline{t_{c}} \cdot \overline{S u_{c}}$ (equation 2).

Substituting equation 2 in equation 1 resulted in equation 3, which was used to calculate the MDC of labor: $\overline{C\left(P_{\imath}\right)_{m o b}}=\sum_{c=1}^{n}\left(\overline{t_{c}} \cdot \overline{S u_{c}}\right)$.

The following intervening variables were defined to measure the total MDC of "CHD session monitoring": mean time spent by each professional category $\left(\overline{\boldsymbol{t}_{c}}\right)$ and mean hourly wage of each professional category $\left(\overline{S u_{c}}\right)$. 
In this study, direct cost is defined as the price attributed to the production of goods or services, which can be traced to a given product or department ${ }^{(17)}$. In hospital units, it basically consists of the direct labor and the materials and equipment directly involved in the care process ${ }^{(18)}$.

Direct labor includes the workers directly involved in the production of goods or services, and can be measured in terms of time spent and professional executing the task. This calculation includes wages, social contributions, paid vacation time, and end-of-year bonus ${ }^{(17)}$.

To measure the direct cost of monitoring CHD, this study recorded the length of $\mathrm{CHD}$ sessions and the number of patients and nursing professionals, per shift, at the three DCs.

The mean number of patients per professional category was represented by the ratio of mean number of patients to the mean number of nursing professionals in each category, per shift. Next, the hourly wage of each professional category $\left(\overline{S u_{c}}\right)$ was divided by the mean number of patients per professional category per shift, and this result was multiplied by the mean length of CHD sessions, resulting in the total MDC.

The hospitals' human resources professionals were asked to fill in an electronic spreadsheet with the wages (base salary, benefits, bonuses, and social contributions) of CHD nursing staff (nurses, nursing technicians, and nursing aides) working at the time of data collection. Even though Ordinance no. 389 of March 13, 2014 ${ }^{(13)}$ does not prohibit the participation of nursing aides in the procedure, it only makes explicit reference to nurses and nursing technicians working in specialized CKD units. In general, at DCs where nursing aides are still employed, they provide operational support in monitoring, identifying and communicating possible complications. Thus, the wages of technicians and aides in Hospitals $A$ and B were joined under one category, "nursing technicians", by finding the weighted mean, as their duties during CHD session monitoring were basically the same. Hospital $\mathrm{C}$ did not have nursing aides. All calculations used the Brazilian real (BRL) as currency.

\section{Analysis of results and statistics}

The data were reviewed, coded, and then recorded on electronic spreadsheets using independent double data entry. Next, pertinent statistical tests were conducted and numeric values analyzed descriptively, using the absolute and relative number of answers. Mean values, standard deviation (SD), minimum and maximum values, mode, and quartiles were presented in charts and tables.

\section{RESULTS}

In the 30-day data collection period, 657 "CHD session monitoring" procedures $\left(\mathrm{P}_{\mathrm{i}}\right)$ were observed. Of these, 331 took place at Hospital A, with a 26 CKD patients/shift capacity; 193 at Hospital B, whose maximum capacity was 8 CKD and AKI patients/shift, and 133 at Hospital C, also with a maximum capacity of 8 CKD and AKI patients/shift.

Twenty-two nursing professionals $(61.11 \%)$ were observed at Hospital A, 13 professionals (30.23\%) at Hospital B, and 7 professionals (100\%) at Hospital C. At Hospital B, the DC is part of a nephrology center, which schedules the same nursing team to work at CHD rooms per month, which allowed us to observe all the professionals working with $\mathrm{CHD}$ during the data collection.

Most of the professionals were women, with $83.3 \%$ among nurses and $92.3 \%$ among nursing technicians/aides at Hospital A; $85.7 \%$ nurses and $75 \%$ technicians/aides at Hospital $\mathrm{B}$ and $100 \%$ nurses and $75 \%$ nursing technicians at Hospital C. The results for mean time working at the DC in Hospital A $(10.63$ years $-S D=8.22), C(10.29$ years $-S D=6.29)$ and $\mathrm{B}(6.53$ years $-\mathrm{SD}=6.91)$ show that the nursing teams were composed of experienced nephrology professionals, corroborating the researchers' choice of these hospitals for their good practices, and advantage of this study.

In terms of nursing professional wages, Chart 1 shows that the mean cost/hour of nurses in the Hospital $C$ dialysis center was 3.24 times greater than at Hospital A, and 1.63 greater than at Hospital B. The mean cost/hour of this category in Hospital B was $1.98 \%$ greater than in Hospital A.

The mean cost/minute of technicians working at the DC in Hospital C was 3.25 greater than the same category in Hospital $A$ and 1.77 greater than in Hospital B, whose mean cost/ minute was 1.83 greater than in Hospital A.

Hospital B presented the greatest monthly workload, 160 hours, followed by Hospitals $\mathrm{C}$ and $\mathrm{A}$, whose monthly workload was 1.11 greater than at Hospital $C$ and 1.33 greater than at Hospital A. Workload at Hospital C was 1.20 greater than at Hospital A.

Chart 1 - Distribution of mean cost per month and mean cost per hour according to the workload of nursing professionals at dialysis centers at hospitals A, B, and C, São Paulo, Brazil, 2014

\begin{tabular}{|c|c|c|c|}
\hline \multirow{4}{*}{$\begin{array}{c}\text { DC } \\
\text { Hospital }\end{array}$} & $\begin{array}{c}\text { Professional } \\
\text { Category }\end{array}$ & $\begin{array}{c}\text { Mean cost/month } \\
\mathbf{( 1 2 0} \text { hours) BRL }\end{array}$ & $\begin{array}{c}\text { Mean cost/ } \\
\text { hour BRL }\end{array}$ \\
\cline { 2 - 4 } & Nurse & $3,791.24$ & 31.60 \\
\hline \multirow{4}{*}{$\begin{array}{c}\text { DC } \\
\text { Hospital } \\
\text { B }\end{array}$} & $\begin{array}{c}\text { Professional } \\
\text { Category }\end{array}$ & $\begin{array}{c}\text { Mean cost/month } \\
\mathbf{( 1 6 0} \text { hours) BRL }\end{array}$ & $\begin{array}{c}\text { Mean cost/ } \\
\text { month (160 } \\
\text { hours) BRL }\end{array}$ \\
\cline { 2 - 4 } & Nurse & $10,054.21$ & 62.84 \\
\cline { 2 - 4 } & Technician/Aide & $4,538.65$ & 28.37 \\
\hline \multirow{2}{*}{$\begin{array}{c}\text { DC } \\
\text { Hospital }\end{array}$} & $\begin{array}{c}\text { Professional } \\
\text { Category }\end{array}$ & $\begin{array}{c}\text { Mean cost/month } \\
\mathbf{( 1 4 4} \text { hours) BRL }\end{array}$ & $\begin{array}{c}\text { Mean cost/ } \\
\text { hour BRL }\end{array}$ \\
\cline { 2 - 4 } & Nurse & $14,746.71$ & 102.41 \\
\cline { 2 - 4 } & Technician/Aide & $7,249.07$ & 50.34 \\
\hline
\end{tabular}

At the three centers, there was a predominance of adult and older adult patients. Eighty-nine patients were observed 
in Hospital $A$, mean age 44.7 years $(S D=17.91) ; 75$ patients at Hospital $B$, mean age $50.82(S D=16.48)$, and 21 patients at Hospital $C$, mean age 65.6 years $(S D=10.62)$.

All of the patients observed in Hospital A had end-stage chronic renal disease (ESRD), and $50.7 \%$ were men and $49.3 \%$, women. Among this group, AV fistulas (69.66\%) were the most frequent form of CHD vascular access. At Hospital $\mathrm{B}, 68.4 \%$ of the patients were men and $31.6 \%$ women and, at Hospital C, $64.6 \%$ were men and 35.4 were women; at both hospitals, the most common form of vascular access was the double-lumen catheter, with $85.71 \%$ and $82.67 \%$ respectively, and patients presented ESRD and AKI.

During this study, 37 transdialysis events were recorded at Hospital B, 16 at Hospital C and 10 at Hospital A. At the center in Hospital $B$, the most frequent events were hypertensive crises $(48.65 \%)$, hypotensive crises $(31.25 \%$ and $30 \%$ ), muscle cramps (25\% and $20 \%)$ and headaches $(12.5 \%$ and $20 \%$ ).

To calculate $\overline{C\left(P_{\imath}\right)}$ "monitoring CHD session", the researchers gathered data regarding the length of each session and the number of patients and nursing professionals, per shift, as shown in Table 1. Hospital A had the greatest mean number of nurses (2.93 - SD $=0.37$ ) and technicians/aides (7.67 $\mathrm{SD}=2.51)$, due to its greater mean number of patients $(19.67$ - $S D=2.24)$, a result of its greater patient capacity.

The mean number of patients cared for at Hospital A was 3.93 times greater than at Hospital $\mathrm{C}$ and 2.46 times greater than at Hospital B, which presented a mean number of patients 1.6 times greater than Hospital C.

Table 1 - Distribution of observations of length of "monitoring conventional hemodialysis session", in hours and minutes, and the number of patients and nursing professionals, by category, at the dialysis centers of hospitals A, B, and C, São Paulo, Brazil, 2014

\begin{tabular}{|c|c|c|c|c|c|c|}
\hline Observations & $\mathbf{n}$ & Mean & SD & $\begin{array}{l}\text { Mini- } \\
\text { mum }\end{array}$ & $\begin{array}{l}\text { Maxi- } \\
\text { mum }\end{array}$ & Mode \\
\hline Hospital A & 331 & & & & & \\
\hline Duration (hours and min.) & & $03: 28$ & $00: 40$ & $01: 30$ & $04: 15$ & 04:00 \\
\hline Patients & & 19.67 & 2.24 & 15.00 & 22.00 & 20.00 \\
\hline Nurses & & 2.93 & 0.37 & 2.00 & 4.00 & 3.00 \\
\hline Aides/Technicians & & 7.67 & 2.51 & 6.00 & 13.00 & 6.00 \\
\hline Hospital B & 193 & & & & & \\
\hline Duration (hours and min.) & & 03:00 & 00:09 & 02:00 & 04:00 & 03:00 \\
\hline Patients & & 8.00 & 0.00 & 8.00 & 8.00 & 8.00 \\
\hline Nurses & & 1.10 & 0.30 & 1.00 & 2.00 & 1.00 \\
\hline Aides/Technicians & & 2.00 & 0.00 & 2.00 & 2.00 & 2.00 \\
\hline Hospital C & 133 & & & & & \\
\hline Duration (hours and min.) & & 04:00 & 00:00 & 04:00 & 04:00 & 04:00 \\
\hline Patients & & 5.00 & 0.00 & 5.00 & 5.00 & 5.00 \\
\hline Nurses & & 1.36 & 0.48 & 1.00 & 2.00 & 1.00 \\
\hline Aides/Technicians & & 1.82 & 0.32 & 1.00 & 2.00 & 2.00 \\
\hline
\end{tabular}

Note: $C H D=$ Conventional hemodialysis; $S D=$ Standard deviation
Next, the mean number of patients was divided by the mean number of nursing professionals per shift, resulting in the mean number of patients per nurse and nursing technician/aides. Then, the mean number of patients per professional category was divided by the value of the mean cost/hour/professional category* $\overline{S u_{c}} \cdot \overline{C\left(P_{\imath}\right)}$ "monitoring CHD session" was obtained by multiplying the last result by the mean length of CHD session (Chart 2).

Chart 2 - Staff costs of "monitoring conventional hemodialysis session", per patient, according to mean number of patients and mean length of conventional hemodialysis sessions, at the dialysis centers of hospitals A, B, and C - São Paulo-São Paulo, Brazil, 2014

\begin{tabular}{|c|c|c|c|c|}
\hline \multirow{4}{*}{$\begin{array}{c}\text { Hospital } \\
\text { A } \\
\text { DC }\end{array}$} & $\begin{array}{c}\text { Mean number of } \\
\text { patients according } \\
\text { to mean number of } \\
\text { nursing professional per } \\
\text { shift }\end{array}$ & $\begin{array}{c}\text { Mean } \\
\text { cost/ } \\
\text { hour/ } \\
\text { patient } \\
\text { (BRL) }\end{array}$ & $\begin{array}{l}\text { Mean } \\
\text { length } \\
\text { of CHD } \\
\text { session } \\
\text { (hours) }\end{array}$ & $\begin{array}{c}\overline{C\left(P_{\imath}\right)} \\
\text { per } \\
\text { patient } \\
\text { (BRL) }\end{array}$ \\
\hline & 6.71 patients/nurse & 4.71 & \multirow{2}{*}{03.28} & 15.45 \\
\hline & $\begin{array}{l}2.56 \text { patients/ } \\
\text { technician/aide }\end{array}$ & 6.05 & & 19.84 \\
\hline & Total staff costs (BRL) & - & - & 35.29 \\
\hline \multirow{4}{*}{$\begin{array}{c}\text { Hospital } \\
\text { B } \\
\text { DC }\end{array}$} & $\begin{array}{l}\text { Mean number of } \\
\text { patients according } \\
\text { to mean number of } \\
\text { nursing professionals } \\
\text { per shift }\end{array}$ & $\begin{array}{c}\text { Mean } \\
\text { cost/ } \\
\text { hour/ } \\
\text { patient } \\
\text { (BRL) }\end{array}$ & $\begin{array}{l}\text { Mean } \\
\text { length } \\
\text { of CHD } \\
\text { session } \\
\text { (hours) }\end{array}$ & $\begin{array}{c}\overline{C\left(P_{\imath}\right)} \\
\text { per } \\
\text { patient } \\
(\mathrm{BRL})\end{array}$ \\
\hline & 7.27 patients/nurse & 8.64 & \multirow{2}{*}{03.00} & 25.92 \\
\hline & $\begin{array}{l}4.00 \text { patients/ } \\
\text { technician/aide }\end{array}$ & 7.10 & & 21.30 \\
\hline & Total staff costs (BRL) & - & - & 47.22 \\
\hline \multirow{4}{*}{$\begin{array}{c}\text { Hospital } \\
\text { C } \\
\text { DC }\end{array}$} & $\begin{array}{l}\text { Mean number of } \\
\text { patients according } \\
\text { to mean number of } \\
\text { nursing professionals } \\
\text { per shift }\end{array}$ & $\begin{array}{c}\text { Mean } \\
\text { cost/ } \\
\text { hour/ } \\
\text { patient } \\
\text { (BRL) }\end{array}$ & $\begin{array}{l}\text { Mean } \\
\text { length } \\
\text { of CHD } \\
\text { session } \\
\text { (hours) }\end{array}$ & $\begin{array}{c}\overline{C\left(P_{\imath}\right)} \\
\text { per } \\
\text { patient } \\
(\mathrm{BRL})\end{array}$ \\
\hline & 3.68 patients/nurse & 27.82 & \multirow{2}{*}{04.00} & 111.28 \\
\hline & $\begin{array}{l}2.75 \text { patients/ } \\
\text { technician/aide }\end{array}$ & 18.31 & & 73.24 \\
\hline & Total staff costs (BRL) & - & - & 184.52 \\
\hline
\end{tabular}

Note: $C H D=$ Conventional hemodialysis; $D C=$ Dialysis Centers; $*$ Hospital $A$ - Nurse: mean cost labor/hour - BRL 31.60; Technician/Aide: mean cost labor/ hour-BRL 15.48; *Hospital B - Nurse: mean cost labor/hour - BRL 62.84; Technician/Aide: mean cost of labor/hour - BRL 28.37; *Hospital C - Nurse: mean cost labor/hour - BRL 102.41; Technician: mean cost labor/hour - BRL 50.34.

Hospital $\mathrm{C}$ presented the greatest mean length of $\mathrm{CHD}$ session (04 hours) and mean cost/hour of nurses (BRL 102.41) and technicians (BRL 50.34), thus obtaining the highest $\overline{C\left(P_{\imath}\right)}$ (BRL 184.52). This value was 5.23 higher than at Hospital $A$ (BRL 35.29) and 3.91 higher than Hospital $B$ (BRL 47.22). The value of $\overline{C\left(P_{2}\right)}$ at Hospital $B$ was 1.34 higher than at Hospital A. 


\section{DISCUSSION}

In terms of the profile of the 185 patients observed at the three DCs, most were adults at Hospitals $\mathrm{A}$ and $\mathrm{B}$, and older adults at Hospital C; male, respectively $50.7 \%, 68.4 \%$ and $64.6 \%$, results similar to those of other studies conducted in Brazil that indicate that the dialysis population is ageing ${ }^{(19-21)}$. Even though AV fistulas are indicated as the preferred form of vascular access, as its numerous benefits to HD patients have been proven, especially in terms of prognosis ${ }^{(22)}$, they were only predominant at Hospital A.

During the observed dialysis sessions, several low-risk clinical complications occurred (hypotensive crises, cramps, headaches and hypertensive crises) ${ }^{(23)}$ requiring immediate nursing assistance. These included: administering saline solutions and/ or pain relief, anti-hypertensive, and hypertonic drugs; interrupting the ultrafiltration rate setting (removing liquid from the intravascular compartment), using the Trendelenburg position; shortening intervals between blood pressure measurements; and providing presence and emotional support. Monitoring patients for low-risk clinical complications is essential, as these can result in more severe events that can lead to greater patient harm.

Thus, "CHD session monitoring" is of vital importance, as nurses, technicians and aides observe patients' signs and symptoms closely, verifying the operation of materials and equipment used, and making assertive decisions to resolve events or minimize consequences. Moreover, the complexity and specificity of CHD patients require investments to guide and help them change attitudes and behaviors that can compromise the therapeutic regimen and reduce quality of life ${ }^{(14)}$.

Dialysis is not an exclusive prerogative of nursing professionals; however, at the studied hospitals these professionals were always present at the DCs, thus confirming the essential nature of their presence to ensure patient safety and quality of CHD. It is worth noting that the quality of the services provided by health organizations is directly related to its staff's technical abilities, interaction and communication skills, working conditions, and the available material resources and support services ${ }^{(24)}$.

The 42 nursing professionals observed in this study monitored CHD sessions with similar rigor, upholding good practices and recommended quality standards $s^{(11-13)}$ and making great efforts to reach the best possible outcome with the resources available. Even though there were no differences in their duties, wages varied considerably among the nursing staff at the three DCs. This was especially true at Hospital C (nursing team: labor/hour - BRL 152.75), which presented a higher $\overline{C\left(P_{2}\right)}$ per patient (BRL 184.52) and whose mean cost/nursing team hour was 3.24 times greater than at Hospital A, and 1.67 greater than Hospital B. Such differences may be related to Hospital C's human resource policy, which includes a nursing career plan, periodic wage increases, and on-call bonuses for Saturday, Sunday and holiday shifts.

Hospital administrators must pay special attention to such differences. In accordance with their respective levels of governability and influence, they should investigate the reasons behind wage disparity and verify the possibility of adopting mechanisms to reassess professional remuneration. This process would adjust wages that do not match the market and each category's duties, in proportion to monthly workload, a well-known source of dissatisfaction among professionals.

Wage review and adjustment depend on institutional human resource policies and the availability of the necessary financial resources. However, managers still need to be aware that incompatible wages with the responsibilities required, this situation can impact and influence workers to leave institutions, compromising the retention of experienced and highly qualified professionals.

Nursing professionals are essential to different areas of health organizations, regardless of field of practice. In addition to developing and expanding their technical and scientific knowledge, they must also be aware of the costs of nursing care in order to ground arguments made to different decisionmaking entities to procure adequate resources ${ }^{(25)}$.

The methodology developed in this study to identify the $\overline{C\left(P_{\imath}\right)}$ of "monitoring CHD session" can be used to systematically analyze work processes and outcomes (benchmarking) at other DCs at hospitals that implement the best nursing practices.

Benchmarking helps organizations adopt the best practices, promoting continuing and interactive learning. In addition to data collection, the process also allows for these practices to be identified, evaluated, adjusted and implemented creatively and innovatively. In this regard, universities are especially valuable, considering their role role in teaching, research and community outreach services ${ }^{(26)}$.

Benchmarking measurements are important to the sustainability and survival of health organizations, especially in the context of teaching hospitals. These facilities are considered references in high-complexity health care, training human resources, developing research, techniques and procedures related to public health, and incorporating new technologies to improve the health condition of the Brazilian population. Moreover, teaching hospitals carry out the most expensive procedures in the public health system ${ }^{(27)}$.

The intensification of financial problems caused especially by the underfinancing of the health area and its growing costs indicates that cost management is a primordial tool for managers $^{(28)}$. When well managed, higher yields can be obtained from scarce resources, including greater part of the population in the public health system ${ }^{(29)}$. Thus, cost management is essential to health institutions, which are currently facing great competitiveness and that seek to provide quality care to patients by incorporating cutting-edge technology $y^{(16)}$.

\section{Limitations of the study}

This study was designed to enable the observation of the greatest number of nursing professionals during $\mathrm{CHD}$ monitoring. However, at Hospitals A and B, the observations did not include all of DC professionals.

Contributions to the field of nursing, health and public policy

The costing methodology developed in this study can be reproduced at other DCs and can even include other procedures that comprise CHD. Thus, it can inform further studies aimed at deepening and complementing the knowledge obtained here and provide managers with tools to address both current and future financial challenges, complying with resolutions and ordinances in force and ensure quality of care for ESRD patients.

Further studies investigating the total MDC of CHD underpin negotiations between hospitals and healthcare payers in 
terms of the necessary human, material, structural and economic resources for its execution.

\section{CONCLUSION}

This multiple-case study conducted at three DCs at teaching and research hospitals enabled the analysis of the MDC of nursing professionals in "CHD session monitoring" procedures. The total MDC was BRL 35.29 at Hospital A, BRL 47.22 at Hospital B and BRL 184.52 at Hospital C.

Hospital C presented the greatest mean length of CHD session (4 hours) and the greatest mean cost of labor/hour for nurses (BRL 102.41) and nursing technicians (BRL 50.34), totaling BRL 152.75, the highest $\overline{C\left(P_{\imath}\right)}$ per patient.

\section{REFERENCES}

1. Leite DS, Camargo NLB, Cordeiro FB, Schuinski AFM, Baroni G. Implications of the use of vascular CDL in hemodialysis patients: analysis of echographic insertion sites. J Bras Nefrol[Internet]. 2014[cited 2016 Jun 20];36(3):320-4. Available from: http://dx.doi. org/10.5935/0101-2800.20140046

2. Mathur AK, Ashby VB, Sands RL, Wolfe RA. Geographic variation in end-stage renal disease incidence and access to deceased donor kidney transplantation. Am J Transplant[Internet]. 2010[cited 2016 Jun 20];10(4Pt2):1069-80. Available from: http://onlinelibrary.wiley.com/ doi/10.1111/j.1600-6143.2010.03043.x/pdf

3. Liu FX, Walton S, Leipold R, Isbell D, Golper T. Financial implications to Medicare from changing the dialysis modality mix under the bundled prospective payment system. Perit Dial Int[Internet]. 2014[cited 2016 Jun 20];34(7):749-57 Available from: https://www.ncbi. nlm.nih.gov/pmc/articles/PMC4269500/pdf/pdi_34_7_012.pdf

4. U.S. Renal Data System, USRDS 2013 Annual Data Report: Atlas of Chronic Kidney Disease and End-Stage Renal Disease in the United States, National Institutes of Health, National Institute of Diabetes and Digestive and Kidney Diseases, Bethesda, MD[Internet]. 2013[cited 2016 Jun 20]. Available from: http://www.usrds.org/adr.aspx

5. Klarenbach SW, Tonelli M, Chui B, Manns BJ. Economic evaluation of dialysis therapies. Nat Rev Nephrol[Internet]. 2014 [cited 2016 Jun 20];10:644-52. Available from: http://www.ncbi.nlm.nih.gov/pubmed/25157840

6. Ramos R, Molina M. Nuevos modelos de gestión de asistencia integral en nefrología. Nefrología[Internet]. 2013 [cited 2016 Jun 20];33(3):301-7. Available from: http://dx.doi.org/10.3265/Nefrologia.pre2013.Feb.11638

7. Bastos MG, Kirsztajn GM. Chronic kidney disease: importance of early diagnosis, immediate referral and structured interdisciplinary approach to improve outcomes in patients not yet on dialysis. J Bras Nefrol[Internet]. 2011[cited 2016 Jun 20];33(1):93-108. Available from: http://dx.doi.org/10.1590/S0101-28002011000100013

8. Rubin R. Dialysis treatment in USA: High costs, high death rates[Internet]. 2009[cited 2016 Jun 20]; Available from: http://usatoday30. usatoday.com/news/health/2009-08-23-dialysis_N.htm?csp=15

9. Leite DS, Camargo NLB, Cordeiro FB, Schuinski AFM, Baroni G. Implications of the use of vascular CDL in hemodialysis patients: analysis of echographic insertion sites. J Bras Nefrol[Internet]. 2014[cited 2016 Jun 20]; 6(3):320-24. Available from: http://dx.doi. org/10.5935/0101-2800.20140046.

10. Brasil. Ministério da Saúde. O SUS de A a Z: garantindo saúde nos municípios. Conselho Nacional das Secretarias Municipais de Saúde. $3^{\text {a }}$ ed. Brasília: Ministério da Saúde[Internet]. 2009[cited 2016 Jun 20]. Available from: http://bvsms.saude.gov.br/bvs/ publicacoes/sus_az_garantindo_saude_municipios_3ed_p1.pdf

11. Brasil. Ministério da Saúde. Agência Nacional de Vigilância Sanitária. Diretoria Colegiada. Resolução-RDC nº 154 de 15 de Junho de 2004. Estabelece o Regulamento Técnico para o funcionamento dos serviços de diálise. Available from: http://www.sbn.org. $\mathrm{br} / \mathrm{pdf} /$ portarias/resolucao154.pdf

12. Brasil. Ministério da Saúde. Agência Nacional de Vigilância Sanitária. Diretoria Colegiada. Resolução-RDC nº 11 de 13 de março de 2014. Dispõe sobre os Requisitos de Boas Práticas de Funcionamento para os Serviços de Diálise e dá outras providências[Internet]. 2014[cited 2016 Jun 20]. Available from: http://portal.anvisa.gov.br/wps/wcm/connect/32cb310043da93a 4969197937783f3a1/rdc0011_13_03_2014.pdf?MOD=AJPERES

13. Brasil. Ministério da Saúde. Agência Nacional de Vigilância Sanitária. Diretoria Colegiada. Portaria no 389 de 13 de março de 2014. Define os critérios para a organização da linha de cuidado da Pessoa com Doença Renal Crônica (DRC) e institui incentivo financeiro de custeio destinado ao cuidado ambulatorial pré-dialítico[Internet]. 2014[cited 2016 Jun 20]. Available from: http://bvsms.saude.gov.br/bvs/saudelegis/gm/2014/prt0389_13_03_2014.html

14. Lima AFC, Fuzii SMO, Pinho NA, Melo ACT, Hashimoto TRF. Processo de Enfermagem na prática de hemodiálise: a experiência das enfermeiras de um Hospital Universitário. Rev Enf Ref[Internet]. 2010[cited 2016 Jun 20];2(12):39-45. Available from: http:// ui.esenfc.pt/rr/index.php?module $=$ rr\&target $=$ publicationDetails\&pesquisa $=\& i d$ artigo $=2170 \& i d$ revista $=4 \& i d \_$edicao $=32$

15. Oliveira WT, Rodrigues AVD, Haddad MCL; Vannuch MTO, Taldivo MA. Conceptions of nurses from a public university hospital regarding the cost management report. Rev Esc Enferm USP[Internet]. 2012[cited 2016 Jun 20];46(5):1184-91. Available from: http://dx.doi. org/10.1590/S0080-62342012000500021

16. Yin RK. Estudo de caso: Planejamento e Métodos. 5a ed. Porto Alegre: Bookman; 2015. 
17. Martins E. Contabilidade de custos. $10^{\mathrm{a}}$ ed. São Paulo: Atlas; 2010.

18. Castilho V, Lima AFC, Fugulin FMT. Gerenciamento de custos nos serviços de enfermagem. In: Kurcgant P.(Coord). Gerenciamento em Enfermagem. $3^{\text {a }}$ ed. Rio de Janeiro: Guanabara Koogan; 2016. p. 170-83.

19. Lopes RF, Silva GB, Silva JWF. Perfil dos pacientes com doença renal crônica em hemodiálise na cidade de Parnaíba-PI. Enciclopédia Biosfera 2010;6(9):1-27.

20. Oliveira HM Jr, Formiga FFC, Alexandre CS. Clinical and epidemiological profile of chronic hemodialysis patients in João Pessoa PB. Bras Nefrol[Internet]. 2014[cited 2016 Jun 20];36(3):367-74. Available from: http://www.scielo.br/pdf/jbn/v36n3/en_0101-2800jbn-36-03-0367.pdf DOI: http://dx.doi.org/10.5935/0101-2800.20140052

21. Santos PR, Arcanjo CC, Aragão SML, Ponte Neto FL, Ximenes ARG, Tapeti JTPC, et al. Comparison of baseline data between chronic kidney disease patients starting hemodialysis who live near and far from the dialysis center. J Bras Nefrol[Internet]. 2014 [cited 2016 Jun 20];36(3):375-8. Available from: http://www.scielo.br/pdf/jbn/v36n3/en_0101-2800-jbn-36-03-0367.pdf

22. Kimball TA, Barz K, Dimond KR, Edwards JM, Nehler MR. Efficiency of the kidney disease outcomes quality initiative guidelines for preemptive vascular access in an academic setting. J Vasc Surg[Internet]. 2011[cited 2016 Jun 20];54:760-5. Available from: http://dx.doi.org/10.1016/j.jvs.2011.03.006

23. Prabhakar, Singh RG, Singh S, Rathore SS, Choudhary TA. Spectrum of intradialytic complications during hemodialysis and its management: a single-center experience. Saudi J Kidney Dis Transpl[Internet]. 2015[cited 2016 Jun 20];26(1):168-72. Available from: http://www.ncbi.nlm.nih.gov/pubmed/25579743

24. Nonino EAPM, Anselmi ML, Dalmas JC. Quality assessment of the wound dressing procedure in patients at a university hospital. Rev Latino-Am Enferm[Internet]. 2008[cited 2016 Jun 20];16(1):57-63. Available from: http://dx.doi.org/10.1590/ S0104-11692008000100010

25. Lima AFC, Fugulin FMT, Castilho V, Nomura FR, Gaidzinski RR. Contribuição da documentação eletrônica de enfermagem para aferição dos custos dos cuidados de higiene corporal. J Health Inform[Internet]. 2012[cited 2016 Jun 20];4(SIIENF):108-13. Available from: http://www.jhi-sbis.saude.ws/ojs-jhi/index.php/jhi-sbis/article/view/239

26. Silva MJ, Leitão J, Leitão D, Raposo M. Como transferir conhecimento em redes de inovação? Uma proposta de benchmarking. Rev Port Bras Gestão[Internet]. 2008[cited 2016 Jun 20];7(2);22-35. Available from: http://www.scielo.mec.pt/pdf/rpbg/v7n2/ v7n2a04.pdf

27. Barata LRB, Mendes JDV, Bittar OJNV. Hospitais de ensino e o sistema Único de saúde. RAS[Internet]. 2010 [cited 2016 Jun 20];12(46):7-14. Available from: http://sistema.saude.sp.gov.br/sahe/documento/ras46.pdf

28. Castilho V, Lima AFC, Fugulin FMT, Peres HHC, Gaidzinski RR. Total staff costs to implement a decision support system in nursing. Rev Latino-Am Enferm[Internet]. 2014[cited 2016 Jun 20];22(1):158-64. Available from: http://dx.doi. org/10.1590/0104-1169.3074.2383

29. Souza AA, Xavier AG, Lima LCM, Guerra M. Análise de custos em hospitais: comparação entre os custos de procedimentos de urologia e os valores repassados pelo Sistema Único de Saúde. ABCustos[Internet]. 2013[cited 2016 Jun 20];8(1):53-67. Available from: http://www.abepro.org.br/biblioteca/enegep2010_tn_sto_115_753_16943.pdf 